\title{
Day Times Microgram per Milliliter Times Kilogram per Milligram
}

National Cancer Institute

\section{Source}

National Cancer Institute. Day Times Microgram per Milliliter Times Kilogram per

Milligram. NCI Thesaurus. Code C132444.

Days times microgram per milliliter, divided by milligrams times kilograms. 